\title{
Introduction: Revisiting EU-Africa relations in a changing world
}

\section{Valeria Fargion and Mamoudou Gazibo}

The central idea of this book is the need to reconsider traditional accounts of dynamics between African states and the European Union (EU), in the light of the major changes that have affected the world economy and global politics since the turn of the century. The current situation and prospects witness a progressive decline in Europe's economic leverage on a global scale, while Africa displays exactly the opposite trend. In contrast to Europe, over the last 20 years, Africa has enjoyed sustained growth, largely due to the demand for its energy, minerals, and other resources. For sure, Africa has been a traditional land of opportunities, and even a backyard for Europe and its member states' companies and entrepreneurs since the colonial era. Europe influenced and shaped economic policies in Africa since independence, from the first Lomé Agreement of 1975 to the Cotonou Agreement of 2000. However, since 2000 Africa has changed a lot. The continent is economically far more dynamic and more attractive and is no longer Europe's exclusive backyard. It has become the place of a 'new scramble' provoked by China, Russia, and other emerging countries like Turkey, India, and Brazil. Therefore, to what extent are these changes leading to a shift in dynamics between the two continents? Is it still correct to depict EU-Africa relations in terms of power asymmetries? Or instead, are these power asymmetries slowly breaking down as a result of Africa's economic empowerment as well as increasing engagement with emerging powers such as BRIC nations?

\section{THE NEED TO RECONSIDER EU-AFRICA INTERACTIONS}

Although economic issues always played a crucial role in EU-Africa relations, to the point that originally the principal instrument of EC/EU external relations was trade preferences, in order to grasp how EU-Africa relations have evolved recently, it is too reductive to focus only on economic aspects. To this purpose, we need to consider also several global challenges that are affecting and will continue to affect the interaction between the two continents. Among these are 
demographic trends and climate change. With respect to the former, current statistical projections indicate that by 2030 Europe will have a median age of 44.7, while the corresponding figure for Africa is 21.3 (ESPAS, 2015). In short, whereas soon Europe will have to cope with the burden of an ageing and diminishing population, Africa will have a young and buoyant population. Regarding climate change, available studies suggest a natural resources 'perfect storm' characterized by increasing desertification in Africa, and extreme weather events in Europe accompanied by highly problematic food, water, and energy shortages.

Under these circumstances, albeit for different reasons compared to the past two centuries, we can expect that Africa will continue to play an important role for Europe and vice versa. First, Africa is in fact a crucial challenge for the EU and its member states. On one hand, the latter will continue to face issues like the recent waves of international migration, not only because Africa is geographically close with the youngest demographic profile worldwide, but also because many African countries facing conflicts and governance problems have so far performed poorly in terms of providing jobs and better conditions of life for its youth. This complex situation also affects European domestic politics strongly, including by influencing partisan competition, and triggering new dividing lines in national political systems, and at the EU level. On the other hand, the International Monetary Fund (IMF) was right when stating that we are confronted with "what seems to be a historic reorientation of sub-Saharan trade and investment" (IMF 2011, p. 39). China has now outpaced its counterparts to become Africa's first trade partner and many other emerging countries are following its example and have increased substantially their cooperation with Africa. Therefore, Europe and its member states' access to Africa's economic resources and markets as well as their political influence on African states is no longer guaranteed.

Second, Europe is also a challenge for African states. On one hand, given the deep historical roots of Europe's influence on the continent, the question is whether the changing pattern of their relations will be peaceful or if Europe and its most powerful member states will be tempted to adopt more coercive and conflictual strategies toward African states and their emerging challengers on the continent. On the other hand, it is not clear if Africa will use the weakening of Europe's influence as a leverage to secure a more balanced and profitable position in the world rather than simply replacing one hegemon (Europe) by another one (China); therefore reproducing the same patterns of domination and rentier economy. Finally, the Ebola epidemic, the COVID-19 pandemic, and terrorist transnational organizations in Europe, in the Sahel region and in East Africa that could travel North-South as well as South-North and that could not be sealed off easily in the context of an increasingly interconnected 
world, remind us that the fates of the two continents are more tightly linked than ever before.

Summing up, this volume aims at revisiting EU-Africa interactions and the mutual influences given the changing environment described above. For sure, EU-Africa relations have been studied in recent years (Faber and Orbie 2009; Ngangjoh-Hodu and Matambalya 2010; Langan 2016; Sicurelli 2016; Barton 2017). But the existing literature is largely interested in the impact of the EU on Africa, and less so in Africa's impact on Europe. Our approach attempts to offer a more balanced view. However, in order to place this book in the context of its contribution to the relevant literature, we need to shed light on the theoretical framework that underpins our understanding of EU-Africa relations. At first sight, it appears rather difficult to interpret the political dynamics that characterize the action of the EU, on the one side, and of African states, on the other, on the basis of a common theoretical apparatus. Despite considerable limitations, on the northern shore of the Mediterranean, the last sixty years witnessed the development of a highly institutionalized supranational system, whereas the continent on the southern shore remains fragmented in a plurality of states with a variety of subregional economic organizations, and contradictory attempts at consolidating an all-encompassing regional authority. Notwithstanding these considerations, in our view some of the theoretical work on European integration as well as comparative and institutional analyses can serve our purpose, by providing valuable insights also on the dynamics at play within the African continent.

\section{THE THEORETICAL FRAMEWORK}

The theoretical framework underpinning this book builds on several literatures. First, almost 30 years on, the analytical lens suggested by Christopher Hill's 1993 seminal article on "The capability-expectations gap, or conceptualizing Europe's international role" offers an extremely fruitful starting point to place into context and understand current EU-Africa relations. Hill conceptualized the then EC-12 as an 'External Relations System'. Notably, Hill discusses what a fully-fledged foreign policy system would look like in the European Community (EC) context by focusing on three crucial factors which refer to the actual capabilities of the EC: its ability to agree, its resources, and the instruments at its disposal. In his words:

a European foreign policy worthy of the name will require an executive capable of taking clear decisions on high politics matters, and of commanding the resources and instruments to back them up. They will need to enjoy democratic legitimacy and also have a sophisticated bureaucracy at their disposal ... A truly European presence in the world would involve collective policies in all major issue areas, thus bringing economics and politics together, as well as rationalizing the decision-making 
process. At present there are elements of collectivity throughout, but the degree and extent of states' commitment to cooperate vary considerably ... What individual states do or do not do in their national foreign policies sets the limits for collective action ... In some ways the external 'pull' of the international system represents a powerful force acting on the EC-12 to acquire the capacity to pursue the tasks which loom before them. But external factors cannot 'federate' without an internal readiness to do so, and domestic factors ... prevent such a condition coming into being ... There is now a large gap between what is expected and what can be achieved. (Hill 1993, pp. 316, 324, 326)

It is our contention that this theoretical framework is still valid to shed light on the current EU external action in so far as it allows us to focus attention on a variety of crucial challenges that EU external relations are facing: first, the lack of cohesiveness among member states concerning foreign policy and national security issues, and their unwillingness to shift the relevant responsibilities to the supranational level; second, the link between domestic politics and foreign policy which poses major constraints on the contents of the latter; third, the EU's inadequate resources and operational capacity (as exemplified - among others - by the relative size of EU funds allocated to internal versus external policies); and, as a result, the gap between the EU's capabilities and the challenges that lie ahead for the continent (power shifts in the global arena, demographic trends, climate change, European economic decline, to name but a few). This is not to say the EU is not a global actor, but to set limits on its 'actorness', and emphasize the 'complex interdependence' between the EU and its member states when it comes to external relations.

Some of Hill's arguments appear very helpful also to place into perspective and understand the African side of the relationship: particularly, Hill's considerations on the limits of the "external pull of the international system" (Hill 1993, p. 325). His words about the lack of an internal readiness to pursue the tasks that loom before European states resonate with Africa's difficulties in strengthening its currently weak position in the international arena, and speaking with one voice, despite its rising economic leverage. Most clearly, this hints at a complex set of factors that are specific to the African context. These include, among others: (a) economic growth is not matched everywhere by a parallel political development, due to the stronghold of traditional power elites in many African states, in spite of rising civil society and youth mobilization calling for democratization; (b) as a result, the political landscape is extremely heterogeneous with more democratic states than in the past but that coexist with many autocratic and hybrid counterparts; (c) there are competing interests among African states that are enhanced by bilateral arrangements with both traditional partners and emerging powers. We certainly acknowledge that the specific elements influencing the EU's interaction with Africa are distinct from those affecting African leaders' behavioral patterns vis-à-vis the EU. 
And yet, with insight, Hill's considerations suggest an intriguing commonality between the EU and Africa that deserves to be brought into focus - namely their relative weakness in the global arena.

Second, to grasp the implications of a relationship between partners that are comparatively weak in the context of the current global order, it is fruitful to complement Hill's theoretical approach with the suggestions put forward by historical institutionalism. We are referring first of all to Paul Pierson's conceptual elaboration of the "restricted time horizons of political decision makers ... that raises a challenge for intergovernmentalist theories of the EC" (Pierson 1996, pp. 135-136). Pierson's arguments convincingly point to short-termism - which, in our view, represents a major feature of current EU external relations. But it is our contention that the concept can also be fruitfully applied to African countries' foreign policies. According to Pierson, “decision makers are frequently most interested in the short-term consequences of their actions; long-term effects are often heavily discounted. The principal reason is that of the logic of electoral politics ... The first concern of national governments is not with sovereignty per se but with creating the conditions for continued domestic success" (Pierson 1996, p. 136). Considering the current political landscape with populism and Euroscepticism on the rise all across Europe, the point made by Pierson can be strengthened even further. One could reframe the argument by saying that member states' domestic concerns and electoral preoccupations are a growing constraint on the EU's attempts to upgrade its foreign policy ambitions, as reflected in the 2016 European Global Strategy - a document revealingly titled "Shared Vision, Common Action: A Stronger Europe". This argument may apply even more to Africa. Despite - and sometimes because of - the democratization process underway since 1990, many African regimes still lack legitimacy and operate on the basis of heritage practices (see below). For these reasons, many of them are unstable as evidenced by the popular revolts of 2019 in Algeria and the coup of 2020 in Mali. Under these conditions, long-term political and economic planning is difficult to foresee.

But this is not our only take on Paul Pierson's theoretical work. His discussion of 'institutional stickiness', 'path dependence', and 'sunk costs' provides us with the building blocks for shedding light on the power dynamics in place between the various Directorates General (DGs) (Hartlapp et al. 2013) involved in external policies and the newcomer in the game, namely the European External Action Service (EEAS). As we are reminded by Pierson (1996, p. 146), in the EU "dense networks of social, political and economic activity have grown up around past institutional and policy decisions": under these circumstances, for the very young EEAS it is extremely hard if not impossible to steer toward whatever new course of action the policies carried out for decades in a variety of institutionally consolidated EU subsystems. 
The EU's external action, in short, appears trapped between two constraints: its ambitions as a global actor are continually undermined by member states' unwillingness to give up more powers to the supranational level - in the light of increasing domestic pressures going in the opposite direction, especially following the international economic and financial crisis. On the internal front, the asymmetrical relations between the DGs with external competencies and the newborn European diplomatic service jeopardize the chances of former EC vice president Federica Mogherini's forward-looking Global Strategy moving from discourse to policy practice.

Based on the above theoretical insights, rather than reflecting a coherent long-term strategy, the current profile of EU relations with Africa appears like a patchwork of policies and interventions that often embody contradictory rationales under the gloss of a new narrative that is largely influenced by short-term preoccupations.

So far, we have suggested that historical neo-institutionalism provides useful lenses for interpreting not only the internal dynamics of European integration but also its external dimension. Concepts such as path dependence and policy legacy - that are central to neo-institutional theory - can also enrich our understanding of the specific policies pursued by the EU and African countries when interacting with each other. Historical legacies are largely responsible for hampering the development of a mutually fruitful relationship between the European and the African continents. The negotiations around Economic Partnership Agreements (EPAs) are a case in point: building on a long history of asymmetrical trade relations, and despite an official discourse based on the concept of 'partnership', the EU proved unable to reorient its priorities in line with African demands, and continued to impose its agenda in the face of widespread opposition. In a nutshell, despite the highly negative consequences for the overall relationship, the evidence concerning this policy area shows that the incremental logic typical of path dependence dominated EU-Africa dynamics. But for the purpose of our argument it is useful to provide another example focusing on the African side. Notably, since the turn of the century many African countries swiftly turned to China and other emerging powers for support concerning development aid and infrastructure despite Western partners' warnings about the potential drawbacks, such as growing financial dependence, very little involvement of the local workforce, dubious construction quality, land grabbing, etc. It is not far-fetched to argue that historical memories and distrust of former European colonial powers played into this bold reorientation of foreign relations - a reorientation that largely seems to reflect short-term calculations.

Third, the last comment brings us back to a problem that the EU and African states seem to share: their major difficulty in defining long-term strategies. We have already discussed at length the issue with respect to the EU, but in 
the case of Africa our argument needs to be qualified. In our view, one has to consider a combination of political and structural constraints that cut across Africa. As for Europe, the background in which political leaders emerge and forge their strategies should not be dismissed. For sure, African states are not all alike. Some of them have developmental capabilities (Bach 2012; Routley 2014). In addition, since 2000 and the acceleration of their relations with China, African development landscapes have changed. For example, between 2001 and 2010, six out of the ten fastest growing economies in the world were African (Angola, Nigeria, Ethiopia, Chad, Mozambique, and Rwanda). Some of the most prestigious economic institutes have issued very optimistic assessments about Africa's future, evoking 'Africa's Lions' (McKinsey Global Institute 2010, 2016). In the same vein, many authors are now working on 'emerging Africa' (Radelet 2010; Rotberg 2013; Gazibo and Mbabia 2020). At the same time, however, many authors have argued that politics continues to be characterized in the majority of African countries by widespread neo-patrimonial practices (Bach and Gazibo 2012). Neo-patrimonialism has several consequences including the weakening of institutions, top-down and arbitrary decision-making processes, and private use of public resources (Médard 1991). In turn, in such a situation, African states and bureaucracies which are among the weakest in the world (Rice and Patrick 2008) lack adequate administrative capacity and the ability to design long-term policies. In sum, institutional weakness and arbitrary politics unfortunately tend to go hand in hand with widespread phenomena of clientelism and corruption and create a ground for the management of public affairs on a day-to-day rather than long-term basis.

\section{FROM THEORY TO EMPIRICAL EVIDENCE: STRUCTURE AND CONTENT OF THE VOLUME}

The above discussion suggests that both the EU and African countries might be punching below their weight in the global arena, with negative consequences also for their relationship, and the prospects of a mutually beneficial cooperation. Against this backdrop, and based on the theoretical framework outlined in the previous section, the volume attempts to shed light on how the interaction between the two continents recently evolved, and is currently unfolding in a selected number of areas that are crucial for the future of EU-Africa relations - particularly for the political implications at the supranational and the national levels of government in Europe, and economic growth and democracy promotion in Africa. The first two parts focus on conflict prevention and migration that have taken centre stage over the last ten years or so, while the third and fourth parts aim at reconsidering the dynamics at play in the two sectors that traditionally dominated EU-Africa relations - namely trade and development 
cooperation - in the context of current global changes. The following part shifts the attention to political development and democratization in Africa, based on the consideration that not only did the latter play a primary role in the EU's 'civilian power' discourse over the recent past but it will also deeply affect the relationship between the two continents in the upcoming years. Finally, the conclusion elaborates on the narrative and the policies currently pursued on both sides in order to identify potential avenues for progress in the EU-Africa partnership.

\subsection{How the Two Continents Are Facing the New Challenges of Security and Migration}

The choice of devoting the first part of the volume to the measures that the EU and the African Union (AU) have put in place to tackle security threats in the Sahel region and the Horn of Africa most clearly reflects our ambition to 'revisit' the literature on EU-Africa relations in the face of the major challenges that the two continents have been confronted with in these last years. The readership does not need to be reminded that terrorist attacks shattered the lives of millions of European citizens in Madrid, Paris, Nice, Brussels, Berlin, Munich, and London - to name only a few. But concurrently, terrorist groups also crept onto African soil, especially following the collapse of the Islamic State and Gaddafi's fall with the breakdown of the Libyan state and the disappearance of the regime's military stockpile to the advantage of terrorist groups and criminal organizations in the region. In Christopher Hill's words, this new situation can definitely be categorized as an "external pull of the international system [that] represents a powerful force acting on" the EU, and for that matter also on the AU (p. 325). But is this enough for the two supranational institutions to "acquire the capacity to pursue the tasks that loom before them" (pp. 325-6)? The chapters in Part I by Daniela Irrera, Lorenzo Angelini, and Reuben J. B. Lewis offer interesting insights and empirical evidence supporting our largely negative expectation. By putting under the radar the 'crime-terror nexus' that is changing the profile of security and stability in a number of African states, Irrera in Chapter 1 provides the first building block for such a critical evaluation. The author offers a toolkit for understanding these non-traditional threats and placing into context the actions carried out to contrast them. The analysis highlights that - albeit for different purposes - terrorist transnational organizations are intermingling with organized crime, but also that intra-state conflict, poverty, corruption, and repressive governments represent the best context for the alliance to thrive. Providing an accurate and multifaceted assessment of this new threat is conducive to a better appreciation of the gap between the complexity of the issue under scrutiny and the limits of the securitized approach that not only the EU but to a large extent also the 
African countries and the AU are endorsing. Irrera questions whether the hard security engagements that characterize the mandate of Common Security and Defence Policy (CSDP) missions in the Sahel managed to achieve their intended goals. While fully acknowledging the need to provide protection to the local population in areas in which terrorist and criminal practices are subverting societal systems with a continuous deterioration of living conditions, the author argues that by focusing exclusively on military-related instruments the EU's action is overlooking the 'root causes' of security vulnerabilities.

Chapter 2 by Lorenzo Angelini elaborates on this crucial point, and highlights that by expanding and deepening the scope of military cooperation, in particular with state authorities that provide inadequate oversight of armed forces' conduct and compliance with international human rights law, the EU's intervention might in fact increase tensions and exacerbate violence. According to Angelini, the crux of the problem lies in the lack of a robust understanding of the local needs and dynamics that underpin the rise of conflicts and instability. Considering civil society organizations are "intimately familiar with local peace and conflict dynamics, stakeholders and power structures, and often have easier access to actors and areas that the government and international actors cannot reach", they could provide a crucial contribution to ensure that engagements are sensitive to local peace, and real conflict dynamics. The many examples provided in the chapter capitalize on the author's engagement as a policy officer at the European Peacebuilding Liaison Office (EPLO), a Brussels-based civil society platform committed to peace-building and the prevention of violent conflict. The evidence also shows that, although the EU has always proclaimed itself as a defender of civil society actors and has put in place a variety of policies to support them, when looking at their range, time frames, and the relevant funding in the African context, the balance unequivocally tilts in favour of defence-related instruments. It is not far-fetched to connect this result to the blurring of boundaries between internal and external security, and the increasingly widespread European public's perception that what is happening on the southern shore of the Mediterranean and in the sub-Saharan region is directly threatening domestic security. Against this backdrop, Paul Pierson's considerations on the need to factor in the 'short-term horizons' of policy makers are largely confirmed, and help close the circle, by shedding further light on the gap between EU ambitions and reality. With respect to the latter, Angelini's sharp conclusion is the following: hard security approaches are "at best insufficient and at worst counter-productive" with the result that the EU might be losing ground and witnessing a decreasing capacity to exercise its leverage in the long term vis-à-vis other powerful actors.

Unfortunately, as Reuben Lewis documents in Chapter 3, the glass remains half-empty even when turning to the African side. The chapter provides a wealth of information on the recent reforms introduced to upgrade the AU's 
capacity to deal with peace, security, and stability issues in the context of a broader set of goals aimed at strengthening its institutional leadership and accelerating the political and socio-economic integration of the continent. The bleak snapshot of the civil conflicts and insurgencies that are ravaging many African countries testifies to the importance and urgency of timely, efficient, and strategically sound responses that, however, do not seem to be in sight. Based on the analysis of the steps taken so far, Lewis exposes the many obstacles that are hindering progress in the implementation of the institution's agenda: first, the lack of collective leadership amongst key states, and second, the difficulties involved in sharing power with institutionally entrenched subregional organizations. The chapter argues that overhauling the AU's cumbersome organizational architecture and upgrading the capacities of its bureaucracy are daunting tasks that - even if fulfilled - will not solve the current problems in the absence of a strong engagement by the member states. The funding issue is revealing: in 2015, in order to overcome the AU's dependence on the support of international donors - which "gives the continent little opportunity to gain equal partnership on the global stage" - the member states committed to finance 100 per cent of the AU's regular budget through a 0.2 per cent levy on eligible imports but there is uncertainty concerning the willingness of member states to adhere to the implementation of this decision. Without going into further details, the evidence presented in the chapter most clearly refers to the three factors that in Hill's reflection are crucial for having a foreign policy worthy of the name; hence, for being able to address high politics issues such as conflict prevention, crisis management, and peace-building. As we suggested in section 2, the elements that make up the African geopolitical landscape are specific to the context, but Hill's theoretical focus on the relative capability of taking "clear decisions ... and of commanding the resources and instruments to back them up" (Hill 1993, p. 316) certainly helps put into perspective the AU's weaknesses, and grasp the dynamics currently at play in the African continent.

Part II of the volume moves to what has become over recent years an obsessive topic in European popular press and public opinion: namely, migration. By providing an objective analysis based on hard data and international scientific research, Chapters 4 and 5 set the stage for an informed discussion of the relevant policies carried out by the EU, on the one hand, and the African side of the story, on the other. As a first step, in Chapter 4 Gustavo De Santis places the European migratory issue in the context of international migration flows, by showing in particular that African immigrants represent an extremely small proportion of the European population, and amount to a very limited contribution to the total share of foreigners living in Europe. The author does envisage a strong increase in Europe-bound African migration; but given the very low starting levels, by mid-century Africans will only constitute around 6 
per cent of the local population. Available data in no way suggest an imminent mass exodus of Africans, as the European populist narrative vocally claims. More importantly, "emigration itself, albeit beneficial, will not be enough to redress the demographic imbalance of the two regions". The final note is that, especially considering the constant decline of its productive population, and notwithstanding the difficulties of a successful integration, in the near future migrants will be an increasingly crucial asset for Europe. In Chapter 5 Alessandra Venturini and Andrea Goldstein complement the above analysis in two different directions: first, by offering a fine-grained picture of mobility and migration in the five main regions of Africa; second, by elucidating the drivers of migration with particular reference to economic, environmental, social, institutional, and political push factors. The authors look into the pros and cons for both sending and receiving countries, and highlight how budget constraints, income differentials, and education levels influence the decision to move to neighbouring countries, in the majority of cases, or outside of Africa, including the Gulf states, Western Asia, and Australia.

The evidence presented in Chapters 4 and 5, and the relevant policy implications are light years away from the misperceptions that characterize the European anti-migration mood which is progressively extending from the far-right to mainstream parties in practically all national political systems. At first sight, the above comment might appear out of place but in fact it hints at one of the main obstacles that prevents the EU from shaping its relationship with Africa on the basis of a solid long-term strategy. If we move to the following three chapters that focus on the actual content of the policies carried out to address migration, the argument we want to make becomes more clear. As, Ioannis Papageorgiou, Rahmane Idrissa, and Andrea Stocchiero illustrate in detail, the bilateral agreements promoted by the EU with African countries, and the variety of measures put in place to address migration reflect European domestic fears and preoccupations far more than a strategic and forward-looking assessment of the interests at stake. In line with the theoretical discussion in the previous section, and the evidence presented in the first part of the volume, migration appears as an emblematic case of the 'complex interdependence' between the EU and its member states, as suggested by Hill (1993), with respect to foreign policy issues or even more abruptly of the major constraints posed by domestic politics on the EU's 'actorness' in the global arena. In order to place into perspective this largely unsatisfactory outcome, Chapter 6 by Papageorgiou calls attention to the particular division of competencies between the EU and the member states which limits significantly the EU's strategic autonomy in this field. Although the right of the member states to determine the volume of admission of third-country nationals (TCNs) hampers the EU from developing a fully-fledged common migration policy, Papageorgiou shows that the EU restrained from enhancing the policy 
inter-linkages stemming from the current legal and institutional frameworks, and endorsed instead a highly reductive approach focused on migration as a security challenge - thereby aligning its policies with the more conservative national orientations that see migration as a threat to internal security. Papageorgiou's discussion of the decisions taken by the EU, especially following the 2015 'refugee crisis', documents how migration management imperatives such as hardening borders, increasing return rates, and keeping displaced persons close to home took priority over all other objectives. This is clearly the case for the projects funded by the EU's Emergency Trust Fund for Africa - originally heralded as the financial instrument at the forefront of the EU's attempts to integrate migration politics, foreign policy, and partnerships for development.

Chapter 7 by Idrissa takes a further step by addressing the drawbacks of such an approach which privileges short-term goals while largely ignoring the African perspective on the issue. Idrissa focuses on EU negotiations with three countries - Nigeria, Mali, and Niger - that acquired a pivotal role in the current tug-of-war on migration, and critically discusses the relevant results. In his words, "Europe's elites have managed to save their (electoral) skin" but at a high cost for both sides. More precisely, as a result of unequal relations the outcomes of the negotiations are not only negative for the weaker party, as one might expect, but tend to be sub-optimal for the goals of the stronger party. Among others, the EU's acquiescence with regard to domestic pressures reflecting the rise in populist rhetoric and its anti-immigration sentiment tarnished the EU's image as a normative leader, with harmful consequences for its leverage in Africa. As Idrissa points out: "the moral stature of the EU was diminished in the eyes of the African elites, who have observed more clearly than in other situations that Europe is quite ready to flout norms of democracy, human rights, and international cooperation in pursuit of questionable goals". This last comment hints at the ambivalence which currently informs the EU's posture in global affairs, and undermines its erstwhile civilian power ambitions. Andrea Stocchiero elaborates on this point in Chapter 8 by recalling that the mainstreaming of migration concerns in EU external policies also contradicts the treaty-based obligation on policy coherence for development. The author puts the interconnection between development and migration under the spotlight. By taking stock of the experience as a practitioner in the civil society and NGO camp, Stocchiero provides a bottom-up approach to the consequences of different development models with particular reference to extractivist models that - as illustrated by two case studies - can trigger a vicious cycle that ends up increasing migration pressure. These findings are in line with the considerations developed by Angelini in Chapter 2. As we outlined above, a short-sighted assessment of the dynamics at play on the ground can backfire on the EU by producing results that are at odds with the intended 
goals. Both Papageorgiou and Stocchiero end their contributions by looking forward and calling for a paradigm shift, but while the former concentrates on the positive implications for Europe, the latter focuses on the corresponding benefits for Africa from a practitioner's perspective.

In sum, there is a common thread that runs through the diverse chapters in Part II of the volume. All the authors share a critical assessment of the inward-looking approach that recently characterized the EU's relations with Africa concerning the global challenges of security and migration. Although the situation is rapidly changing, the EU persists in imposing its agenda and priorities rather than trying to reach a common understanding of the challenges that the two continents are facing and paying due attention to aspects such as diasporas and remittances. However, as Idrissa usefully points out in discussing the implementation of the abovementioned EU negotiations with three countries in the Sahel region, power asymmetries are breaking down, and the political landscape might look quite different in a very short time. Yet, there seems to be a long way to go before the African continent is able to speak with one voice. The AU did manage to formalize its main priorities in a number of official documents, as Stocchiero usefully illustrates, but was unable to get them to the EU negotiating table - due to the internal divisions among its member states, and the consequent limited handover of powers from the national governments and the more consolidated regional organizations - as highlighted in Idrissa's chapter.

\subsection{EU-Africa Relations in the Traditional Fields of Interaction: Trade, Investment, and Development Cooperation}

Parts III and IV in the volume shift the attention to the two policy areas that were traditionally at the forefront of EU-Africa relations, and largely catalysed policy makers' attention. While the role of member states remains an important element in the explanation of the dynamics under scrutiny in both continents, the chapters addressing economic and development cooperation issues add two further interpretative lenses in order to provide a more accurate assessment of whether - in the face of the deeply changing world landscape - European and African behavioural patterns reflect a disruptive trajectory, or remain anchored to long-term trends. The first is the historical lens that is used in the opening chapters of both parts - i.e. Chapter 9 by San Bilal, Bernard Hoekman, and Dominique Njinkeu, and Chapter 12 by Niels Keijzer - in order to place into perspective the more recent developments. The second is an organizational lens which allows to shed light on evolving intra- and inter-institutional dynamics that appear crucial for the current outcome of EU-Africa relations in the fields under consideration. 
Albeit reflecting distinct features, up until very recently, in both sectors policy making displays the incremental and path-dependent rationale typical of neo-institutionalist accounts of decision processes. In the case of development cooperation, based on a careful reading of official statements and documents, Keijzer goes all the way back to the early days of the EC in order to document step after step how the European Commission managed "to carve out a specific niche for the Community's development policy vis-à-vis the bilateral development policies of the member states, but also in relation to the development cooperation engagement of the International Financial Institutions and the United Nations". The author discusses how the Commission's standing as a development actor was progressively upgraded by going from an initial situation in which the absence of a legal basis in the treaties was compensated by resorting to international agreements, to the Maastricht Treaty's codification of the Commission's action as complementary to the member states' policies, and, finally, to the two-way complementarity endorsed by the Lisbon Treaty. Although in no way comparable to the capacity for autonomous action which DG Trade enjoyed - as illustrated by Bilal and his co-authors - especially following Santer's resignation, the Commission's units dealing with development cooperation were able to promote a development blueprint emphasizing the concepts of poverty reduction, policy coherence, long-term planning, aid effectiveness and ownership "at least at the discursive level" (Keijzer). We shall come back to this last qualification as it pertains to the gap existing between the official narrative and the relevant policy practice which is addressed in Chapter 14 by Fargion and Mayer.

In a similar vein to Keijzer's, Bilal and his co-authors start their analysis of EU-Africa trade and investment relations with a historical reflection - although taking a medium rather than a long-term perspective. Their discussion pays special attention to the EPAs which are, in their view, a perfect example of the EU's entrenched prioritization of market access considerations aimed at reducing trade costs for European firms in foreign markets. More precisely, the authors argue that DG Trade was able "to protect its prerogatives regarding EU trade policy, and resisted a more political and geostrategic approach to the EPA negotiations" - disregarding the deep resentment generated by the EPA process in many African countries, at the highest political levels. Their account fits perfectly into the neo-institutionalist theoretical apparatus discussed in section 2, with its emphasis on institutional inertia, and particularly on the constraints exerted on decision-making processes by the legal framework, 'sunk costs', and the differential resources accumulated over time by the key actors.

However, as the relevant chapters illustrate, recent years have seen a deviation from the original path-dependent trajectories. In neither case does this lead to a fundamental reorientation of goals and practices; but certainly, recent policy making reflects the seeds of change in both areas. The authors' analyses 
suggest a distancing from the traditional silo approach in which at best the left hand does not know what the right hand is doing, while in most cases the outcome of the decisional process inside the Commission is the sheer result of power-balance dynamics amongst the various DGs with the inevitable consequence of a patchwork of interventions marked by contradictory side effects. In the case of trade, Bilal et al. document the EU's clear attempt at coordinating internally the various policies: the attempt unfolds in three steps and culminates with the 2017 EU External Investment Plan (EIP) which is, in their view, "a systemic effort by the EU to pursue a more coherent and coordinated approach to stimulate sustainable investment in Africa and European neighbourhood countries". Yet, their overall conclusion unequivocally suggests that the ongoing process falls short of a far-sighted strategy aimed at setting the relationship with Africa on truly new grounds: "the EIP has been a very Euro-centric process, driven by European considerations, with no consultation with Africa".

Keijzer also acknowledges a discontinuity in the recent evolution of development cooperation but with even more negative overtones. He argues that "Since the start of the Juncker Commission in 2014, the EU's motivation for its development policy essentially moved from complementing the member states, based on an understanding of what makes the EU different from a state, to one of copying the member states - the EU as a big state." More precisely, in contrast to the 2005 European Consensus on Development, the 2017 new Consensus "neither determined specific comparative advantages for the EU, nor presented any clear prioritization whatsoever ... the statement embraced the broad and inclusive 2030 Agenda on Sustainable Development ... [but] refrained from identifying those SDG targets that could be best promoted at the European level". The new turn which emphasized speed of delivery, results, and flexibility coincided with the European Council's hitherto unexpected engagement with this policy area - which lends support to the "view that development policy is subordinate to (or a function of) the EU's foreign policy". In itself, the latter consideration does not have a negative connation: the fact that development cooperation was pulled out of its niche could actually represent a positive trend. But there is certainly a problem if development goals are subsumed to foreign policy priorities that are increasingly captured by member states' rising populist demands and mounting Euroscepticism.

However, in order to fully appreciate the limits of the abovementioned changes in the two sectors under scrutiny, it appears most fruitful to go back once more to the arguments presented in section 2 on the explanatory power of the neo-institutionalist theory, focusing in particular on its actor-centred version. By taking this approach, first we want to suggest that the context in which the above new trends are emerging can be considered as a 'critical juncture' in both Europe and Africa. In the former case, our assessment does not 
require much justification as there is an overwhelming literature that discusses how the international financial and economic crisis, the massive attack on the euro, and the subsequent austerity policies represented a watershed in the European integration process that opened the way to mass politics dynamics, and therefore to a deep-ranging shift from 'permissive consensus' to 'constraining dissensus'. It is our contention that the same time period, albeit for entirely different reasons, represents a critical juncture also for Africa. In our view, the collapse of Gaddafi's regime in 2011, following a dramatically shortsighted international intervention, and the Arab Spring movements represent a turning point in the African political landscape which is now increasingly marked by political upheavals, transnational terrorist threats, and failed states with a rising number of displaced persons and a deterioration of living conditions in many areas, despite the economic progress in some countries. We shall address later on the relevant implications for the African continent but at the moment we want to complete our discussion of the dynamics at play on the EU side.

The neo-institutional theoretical framework suggests that whereas policy making is mostly of an incremental nature and follows a path-dependent trajectory, in the case of a critical juncture, actors have unexpected opportunities at their disposal. It is in those historical moments that paradigm shifts are possible depending on the actors that are actually involved and the substantive content of their choices. In the light of the abovementioned results, arguably European policy makers proved unable to go all the way to meet the geopolitical challenges lying ahead of them and settled for a compromise primarily aimed at tackling inter-institutional dynamics - particularly, between the newly established EEAS and specific Commission DGs - while at the same time attempting to appease domestic vocal pressures.

By moving from the Brussels scene to how development policies have actually been implemented on the field, Chapter 14 by Valeria Fargion and Marco Mayer adds a further perspective. The chapter reviews the priorities which the EU and African countries agreed for the tenth and the eleventh planning periods of the European Development Fund (EDF) - hence covering the years from 2008 to 2020 - and highlights how the EU's aid marginalized the support for health and education - despite their paramount importance in the UN Millennium Development Goals (MDGs) and despite the fact that, from 2000 until the endorsement of the Sustainable Development Goals (SDGs), the EU's discourse constantly referred to the MDGs as the cornerstone of its engagement on development cooperation. The empirical evidence in the chapter also sheds some light on the ambiguities and the potential drawbacks of the ownership principle enshrined in the EU's narrative. Spending data on health development assistance (Official Development Assistance - ODA) confirm the secondary role played by the EU compared to the bilateral contributions of 
its member states, and Europe's progressively decreasing relevance in global health financing. The information provided in Chapter 14 stands in sharp contrast to the EU's 2010 strong commitment to improving health throughout the world, and its emphatic declarations on 'health as the greatest wealth'. But more importantly, and based on a multifaceted evaluation of Europe's competitive advantage in the health sector, it elaborates on the benefits that both continents could gain from a truly forward-looking reorientation of their strategies that factors in the crucial role of health issues for de-escalating conflict dynamics and strengthening democratic processes - as the European welfare states historical record demonstrates. Yet not even the current COVID-19 pandemic convinced the relevant actors to get social and health objectives on the list of priorities in the ongoing EU-Africa negotiations.

The latter comment brings us to Chapter 13 by Maurizio Carbone. The chapter unravels the complex interactions that involved over the last three years a variety of African and European key actors in an intricate web of negotiating tables set up to define the post-Cotonou framework. Notably, since June 2000, the Cotonou Agreement governed relations between the EU and the African, Caribbean, and Pacific (ACP) group of states - therefore playing a crucial role for the 48 sub-Saharan countries. In his capacity as expert, Carbone offers a most valuable inside view that allows the readership to grasp the main controversial issues underpinning the official talks. In this light, the negotiations appear a litmus test for Africa's difficulties to forge common positions and speak with one voice. The chapter discusses the conflicts occurring at two different levels: on the one hand, the structural clash between the ACP and AU institutions, with the latter portraying the ACP group as a relic of post-colonialism, and an obstacle to Pan-Africanism; on the other hand, the contrasting interests of some African states, as exemplified by Northern African states insisting on maintaining their preferential agreements with the EU, and West African states preferring to operate within the less stringent ACP framework and opposing further handover of powers to the AU. In this context, and by recalling Pierson's arguments about 'history matters' and 'institutional stickiness', it comes as no surprise that the ACP managed to protect itself from "the existential threats posed by the May 2018 AU decision to dismantle the EU-ACP framework". From the opposite perspective, the message is that "The AU succumbed to the view that another actor could legitimately represent the interests of Africa vis-à-vis third parties". Once more, we are confronted with a middle-range solution - in this case, between preserving the legacy of a long-standing partnership, and boosting the AU's credibility with respect to its member states, thereby also increasing Africa's agency in the international arena.

The post-Cotonou negotiations are, definitely, crucial for the future of EU-Africa relations but there is a concurrent initiative that is equally impor- 
tant, and deserves careful consideration: the Africa Continental Free Trade Area (AfCFTA) - which was launched in 2018 and became operational at the beginning of 2021. The topic is addressed extensively by John Akokpari in Chapter 10, but to get the full picture it is most fruitful to read it in parallel to section 4 in Chapter 9 since the two analyses complement each other perfectly by looking at different sides of the same coin. While acknowledging there are many issues that need to be addressed, Bilal et al. portray the AfCFTA as "a relevant political anchor for cooperation between the two continents", and concentrate attention on the measures to enhance Africa's economic transformation: "EU and African policymakers need to think in terms of goods and services given the trends towards servicification and digitization of economic activity ... Much of the trade policymaking challenge in Africa in the post-2020 period will centre on non-tariff policies such as regulatory standards, connectivity to networks of land, air and maritime transport, and other core services such as distribution, finance, and professional services". Akokpari dwells instead on a variety of structural limits that can jeopardize the projected benefits of AfCFTA: first, the so-called 'fallacy of agricultural composition', according to which production of similar commodities by countries within the same region undermines intra-African trade; second, the harmful effects of free trading between unequal partners that will exacerbate the uneven distribution of gains and losses, and potentially rekindle historic rivalries. More specifically, South Africa's potential economic dominance in the emerging common market can suffocate sub-Saharan nascent industries, while at the same time triggering unexpected reactions by endangered "Subregional hegemons - Nigeria in ECOWAS, Kenya in EAC, Cameroon in ECCAS and Egypt in AMU/UMA". Finally, the negative socio-economic impact of COVID-19 might push African countries to be "more focused on revitalizing bruised economies and restoring employment levels than engaging in trade with fellow African countries". While enriching and reinforcing Lewis' considerations (in Chapter 3) on African power dynamics, and the implications of states' overlapping memberships, from a theoretical angle the evidence in Chapter 10 fully supports the usefulness of Hill's approach beyond the European context. From a factual point of view, although AfCFTA's effective trade-off between costs and benefits remains to be seen, Akokpari's final assessment is that the EU will continue to be a critical trading partner for Africa.

Interestingly, in Chapter 11, Giorgia Giovannetti, Enrico Marvasi, and Filippo Santi reach exactly the same conclusion from a completely different starting point. Based on an econometric approach, the three authors investigate whether and how sub-Saharan Africa (SSA) countries could benefit from Brexit in terms of increased trade. This is not only a topical issue but has been presented by Prime Ministers Theresa May and Boris Johnson as 
a major challenge for the "British attempt to reconfigure its economic network worldwide". Especially considering that four of the largest economies in the continent - South Africa, Nigeria, Ghana, and Kenya - are also members of the Africa Commonwealth, the topic merits reflection. First, the data in the chapter show that trade links between the UK and SSA weakened over time and that there are unexploited opportunities or, to put it differently, trade gaps that the post-Brexit reconfiguration of trade agreements could shrink or widen. Second, the authors discuss four counterfactual scenarios - ranked from the more optimistic to the more pessimistic - in order to capture possible changes in trade flows. Without going into the technical details, the results of the relevant analysis imply, on the one hand, that "the direct effects of Brexit are not likely to benefit SSA as much as the Brexit narrative has suggested, even without considering the severe impacts the recent COVID-19 pandemic had globally", and, on the other hand, that "the ties with the EU do not fade away".

\subsection{Africa between Continuity and Change and the Prospects for EU-Africa Relations}

Last but not least, Part V of the book is devoted to the issue of governance and democracy. For many reasons, this issue offers one of the best avenues for revisiting EU-Africa relations. The main one is that the dramatic changes that have occurred in the international arena since Africa launched its democratic experiments in the early 1990s may have negative impacts on the sustainability of EU democracy promotion policies while giving to African countries more partners and more leverage vis-à-vis their European counterparts. In addition, the gains and setbacks as well as the domestic and international determinants of democracy in Africa illustrate very well the theoretical arguments presented above regarding the capability-expectation gap, the institutional stickiness, and the mixed messages of positive changes in the economic realm alongside neo-patrimonial practices in Africa.

In their chapter, Arrigo Pallotti and Corrado Tornimbeni offer an overview of the evolution of the African political systems in order to explain the current 'disappointing' state of the democratic process launched in 1990. They point out an institutional inertia, and, in line with our theoretical framework, argue that "the impasse of the democratization processes in sub-Saharan Africa should be understood within the framework of both the specific historical trajectory of the African political systems and the international community's waning commitment to democracy promotion". This was true in the Cold War era during which the EU and its member states unquestionably supported African authoritarian regimes. It is also true after 1990, despite the EU and other Western partners' democracy promotion policies, for various reasons among which security and anti-terrorism are prominent factors. Chapter 16 by 
Thilo Bodenstein focuses on a more specific policy devised by the EU, namely the 'Everything But Arms' (or EBA) initiative, as EBA grants duty-free and quota-free access to the European market for all products except arms in order to improve good governance (GG) in SSA. Bodenstein then examines whether international trade helps foster GG as expected by the EU. He argues that "international trade influences the distribution of power between domestic coalitions and thus the stability of existing government structures". However, this is not automatic but indirect and requires some favourable domestic conditions such as a diversified export structure and reforms, and the protection of newly empowered export coalition groups. His conclusion confirms the capability-expectation gap arguments we are making in this book: "EU conditionality and the EU as the main export destination play no role in good governance". Given the indirect relation between EBA and GG, he nonetheless advises the EU to reform its policies accordingly by focusing on the conditions allowing a positive impact of the former on the latter such as export diversification and the emergence of a middle class.

Part V ends with Mamoudou Gazibo's chapter, which continues the two previous discussions. As we know, the end of the Cold War and the collapse of the Eastern bloc made African countries vulnerable because the EU, its member states, and other Western countries were no longer interested in supporting African autocrats. These external actors have imposed conditionality policies upon African regimes and contributed to force them to open their political space. Since then, however, China rose as Africa's main commercial partner, making observers worried that this situation contributes to the reversal of democratic gains on the continent. Gazibo provides an overall assessment of the democratic accomplishments on the continent as well as case studies. He argues that the EU and its member states' push for democracy has been less successful than expected, and that there is no evidence that China is undermining Africa's democratic gains. His study confirms the capability-expectation gap and argues that African domestic dynamics should be taken seriously when it comes to the fate of democracy on the continent.

We conclude the book with Chapter 18 by Pasquale Ferrara. By reflecting on the European Global Strategy and EU Neighbourhood Policy in the context of the COVID-19 pandemic, his chapter identifies some conceptual and analytical tools to assess it; but it also offers a summary of the main findings of the other contributions. First, Ferrara acknowledges the "huge gap between the original ambition of the Euro-African strategy and its concrete achievements", pointing also, on the African side of the problem, at several fragilities - ethnic divisions, conflicts, neo-patrimonialism - that limit the prospects for the current Euro-African or Pan-African ambitions despite Africa's ambitious Agenda 2063 envisioning “an integrated, prosperous, and peaceful Africa, driven by its own citizens and representing a dynamic force in 
the global arena" (African Union Commission 2013). These hindering factors also illustrate the weight of institutional inertia and the prolonged effect of the neo-patrimonial governance which fuels conflicts and divisions. Second, Ferrara warns that Africa is no longer Europe's backyard, but an arena of competition between the EU and other powers. This is due to the rapid and growing presence of emerging countries like China; a country which is always 'the stone guest' even when not explicitly mentioned.

\section{REFERENCES}

African Union Commission (2013). Agenda 2063: The Africa We Want. Addis Ababa: African Union.

Bach, D. (2012). Patrimonialism and neopatrimonialism: Receptions and transcriptions. In D. Bach and M. Gazibo (eds), Neopatrimonialism in Africa and Beyond. London: Routledge, pp. 25-45.

Bach, D. and Gazibo, M. (eds) (2012). Neopatrimonialism in Africa and Beyond. London: Routledge.

Barton, B. (2017). Political Trust and the Politics of Security Engagement: China and the European Union in Africa. New York: Routledge.

European Strategy and Policy Analysis System (ESPAS) (2015). Global Trends to 2030: Can the EU Meet the Challenges Ahead? Luxembourg: Publications Office of the European Union.

Faber, G. and Orbie, J. (eds) (2009). Beyond Market Access for Economic Development: EU-Africa Relations in Transition. London and New York: Routledge.

Gazibo, M. and Mbabia, O. (2020). Index de l'émergence en Afrique 2019, 2nd ed. Montréal: Prame. Accessed June 12, 2020 at https://www.giersa.ulaval.ca/nouvelles/ index-de-lemergence-en-afrique-2019-2e-edition.

Hartlapp, M., Metz, J., and Rauh, C. (2013). Linking agenda setting to coordination structures: Bureaucratic politics inside the European Commission. Journal of European Integration, 35(4), pp. 425-441.

Hill, C. (1993). The capability-expectations gap, or conceptualizing Europe's international role. Journal of Common Market Studies, 31(3), pp. 305-327.

International Monetary Fund (2011). Regional Economic Outlook: Sub-Saharan Africa - Sustaining the Expansion. October. Washington, DC: IMF.

Langan, M. (2016). The Moral Economy of EU Association with Africa. London and New York: Routledge.

McKinsey Global Institute (2010). Lions on the Move: The Progress and Potential of African Economies. New York: MGI.

McKinsey Global Institute (2016). Lions on the Move II: Realizing the Potential of Africa's Economies. New York: MGI.

Médard, J.-F. (1991). L’État néo-patrimonial en Afrique noire. In J.-F. Médard (ed.), États d'Afrique noire: Formation, mécanisme et crises. Paris: Karthala, pp. 323-353.

Ngangjoh-Hodu, Y. and Matambalya, F. (eds) (2010). Trade Relations between the EU and Africa: Development, Challenges and Options beyond the Cotonou Agreement. London and New York: Routledge.

Pierson, P. (1996). The path to European integration: A historical institutionalist analysis. Comparative Political Studies, 29(2), pp. 123-163. 
Radelet, S. (2010). Emerging Africa: How 17 Countries Are Leading the Way. Washington, DC: Brookings Institution.

Rice, S. and Patrick, S. (2008). Index of State Weakness in the Developing World. Washington, DC: The Brookings Institution. Accessed May 25, 2020 at https://www .brookings.edu/wp-content/uploads/2016/06/02_weak_states_index.pdf.

Rotberg, R. (2013). Africa Emerges: Consummate Challenges, Abundant Opportunities. Cambridge: Polity Press.

Routley, L. (2014). Developmental states in Africa? A review of ongoing debates and buzzwords. Development Policy Review, 32(2), pp. 159-177.

Sicurelli, D. (2016). The European Union's Africa Policies: Norms, Interests and Impact. London: Routledge. 